\title{
Penggunaan Geoda Untuk Pemetaan Bencana Alam di Kabupaten Karanganyar
}

\author{
Hasih Pratiwi ${ }^{1}$, Niswatul Qona'ah ${ }^{2}$, Kiki Ferawati ${ }^{3}$, Sri Sulistijowati Handajani ${ }^{4}$, \\ Respatiwulan ${ }^{5}$, Yuliana Susanti ${ }^{6}$, Muhammad Bayu Nirwana ${ }^{7}$ \\ Universitas Sebelas Maret, Surakarta \\ hasihpratiwi@staff.uns.ac.id.
}

\begin{abstract}
Abstrak
Kemampuan mengolah data menjadi kebutuhan di masa kini, apalagi dengan banyaknya data yang tersedia yang dapat diakses secara bebas. Statistika dapat digunakan untuk membantu masyarakat dalam menjelaskan dan memahami gambaran tentang kejadian bencana alam. Karanganyar, yang terletak di Provinsi Jawa Tengah, merupakan salah satu kabupaten di Indonesia yang rawan bencana alam. Oleh karena itu, diperlukan visualisasi data sebagai upaya untuk memberikan pemahaman kepada masyarakat tentang bencana alam yang terjadi di wilayah Kabupaten Karanganyar. Pemetaan bencana alam dengan Geoda dapat memberikan informasi kondisi kecamatan-kecamatan di Karanganyar yang rawan bencana alam. Untuk menyusun peta, diperlukan data bencana alam serta file peta wilayah. Setelah program Geoda terinstal, peta dapat disusun melalui menu toolbar, mengurutkan kolom kode kabupaten, create project file, dan map. Peta spasial menunjukkan bahwa tanah longsor sering terjadi di wilayah Kabupaten Karanganyar bagian timur yang berbatasan dengan Kabupaten Magetan di Jawa Timur, kebakaran di bagian tengah, dan angin ribut di bagian utara.
\end{abstract}

Kata Kunci: statistika, Geoda, bencana alam, Karanganyar

\section{PENDAHULUAN}

Kemampuan mengolah data menjadi kebutuhan di masa kini, terlebih dengan banyaknya data yang tersedia yang dapat diakses secara bebas. Statistika dapat digunakan untuk membantu masyarakat dalam menjelaskan dan memahami gambaran tentang kejadian bencana alam. Data spasial adalah data yang diperoleh dari hasil observasi yang memuat dua informasi, yaitu lokasi dan variabel penelitian. Data bencana alam di Kabupaten Karanganyar dapat dikategorikan ke dalam jenis data spasial karena memuat informasi lokasi (kecamatan) dan variabel penelitian (jumlah kejadian bencana). Visualisasi data bencana alam Kabupaten Karanganyar dibutuhkan untuk memberikan gambaran yang lebih informatif dan menarik tentang fenomena bencana alam tersebut.

Pengetahuan tentang intensitas terjadinya bencana serta gambaran bencana alam yang terjadi di wilayah Karanganyar akan membantu masyarakat dalam memahami kejadian yang berpotensi untuk terjadi di sekitar mereka, sehingga diharapkan masyarakat akan lebih mempersiapkan diri sebagai tindakan preventif sebelum terjadinya bencana alam (Zhou et al., 2018; Ahmed, 2013). Saat ini, ada banyak sekali data dan informasi yang dapat diakses oleh semua orang, tetapi keterampilan dalam membaca, memahami dan menarik kesimpulan dari data masih perlu untuk dilatih.

Statistika adalah ilmu yang mempelajari tentang cara mengumpulkan, menabulasi, menganalisis, dan mencari keterangan dari data. Penelitian statistika kebencanaan yang telah dilakukan diantaranya oleh Pratiwi dkk. (2014) serta Furqon dan Muflikhah (2016) yang membahas pemodelan stokastik untuk mitigasi bencana alam. Statistika dapat digunakan untuk membantu masyarakat dalam menjelaskan dan memahami gambaran tentang kejadian bencana alam.

Lingkungan Hidup dan Kebencanaan 
GeoDa adalah program perangkat lunak yang ramah pengguna yang telah dikembangkan sejak tahun 2003 untuk mendukung infrastruktur penelitian analisis data spasial. Artikel ini membahas cara memvisualisasikan data bencana alam di Kabupaten Karanganyar yang merupakan data spasial menggunakan software Geoda. Dengan Geoda data bencana alam di Kabupaten Karanganyar dapat disajikan dalam bentuk peta yang lebih menarik dan informatif.

\section{BENCANA ALAM DI KABUPATEN KARANGANYAR}

Kabupaten Karanganyar merupakan sebuah kabupaten yang berada di wilayah Provinsi Jawa Tengah. Secara astronomis, Kabupaten Karanganyar terletak antara $110^{\circ} 40^{\prime \prime}-110^{\circ} 70^{\prime \prime}$ BT dan $7^{\circ} 28^{\prime \prime}-7^{\circ} 46^{\prime \prime} \mathrm{LS}$, berbatasan langsung dengan Kabupaten Magetan, Provinsi Jawa Timur di sebelah timur, Kota Surakarta dan Kabupaten Boyolali di sebelah barat, Kabupaten Sragen di sebelah utara, serta Kabupaten Wonogiri dan Kabupaten Sukoharjo di sebelah selatan. Secara administratif, Kabupaten Karanganyar terdiri dari 17 kecamatan (BPS Kab. Karanganyar, 2019). Peta Kabupaten Karanganyar beserta informasi mengenai pembagian wilayah kecamatannya dapat dilihat pada Gambar 1 (Kabupaten Karanganyar, 2011).

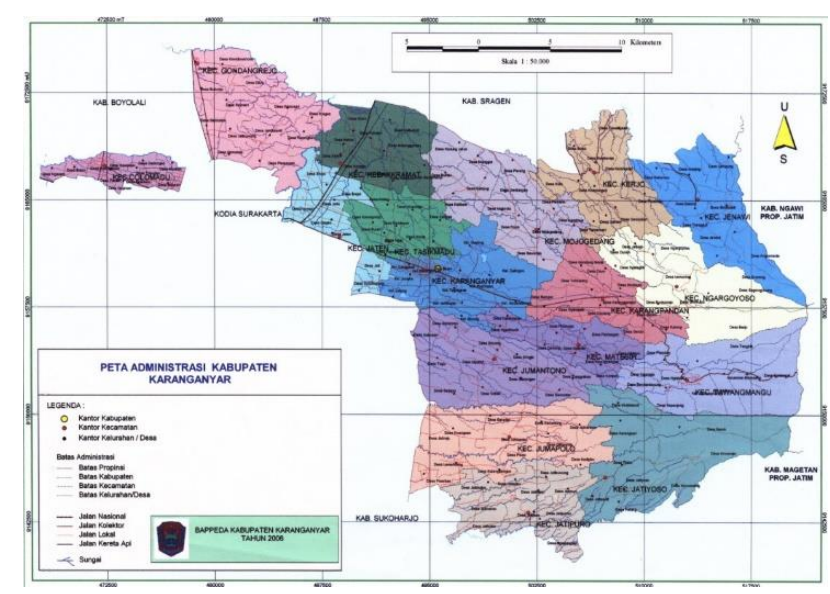

Gambar 1. Peta Kabupaten Karanganyar

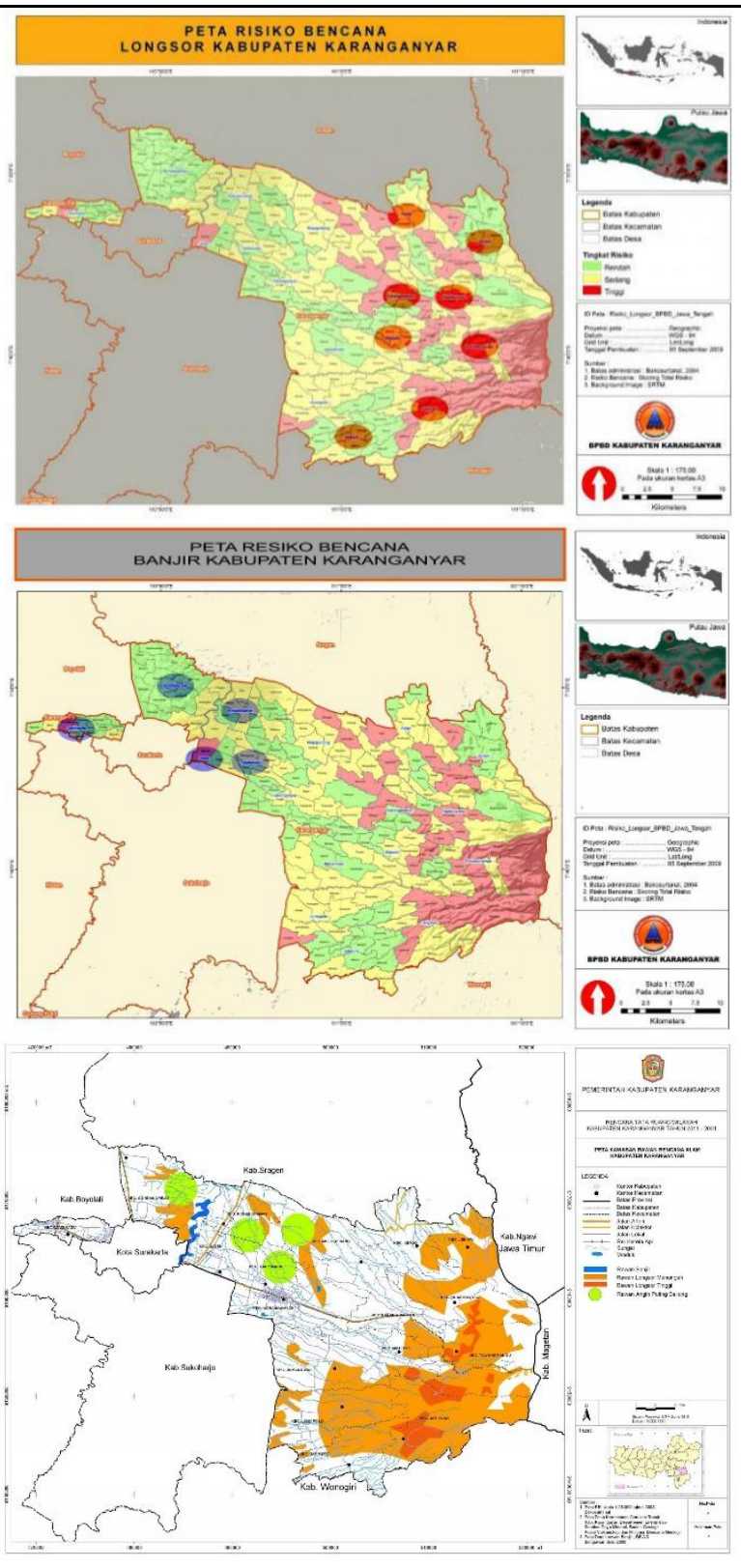

Gambar 2. Peta Rawan Bencana di Kabupaten Karanganyar

Sebagian lokasi Kabupaten Karanganyar berada di lereng dan kaki Gunung Lawu. Rata-rata ketinggiannya terletak di 511 meter di atas permukaan air laut. Selama tahun 2018, curah hujan tertinggi terjadi di bulan Januari sebesar 519,2 mm dan curah hujan terendah terjadi pada musim kemarau, dengan curah hujan mendekati $0 \mathrm{~mm}$. Pada bulan di musim penghujan, terjadi bencana banjir dan longsor di beberapa wilayah di

Lingkungan Hidup dan Kebencanaan 
Kabupaten Karanganyar. Tahun 2019, BPBD Kabupaten Karanganyar menerbitkan Peta Rawan Bencana untuk beberapa jenis bencana alam yang sering terjadi di Karanganyar.

\section{METODE}

Data yang digunakan untuk analisis dalam artikel ini merupakan data sekunder yang diperoleh dari Badan Nasional Penanggulangan Bencana (BNPB) Kabupaten Karanganyar. Variabel penelitian merupakan data jumlah kejadian bencana tanah longsor berdasarkan kecamatan di Kabupaten Karanganyar pada Tahun 2016-2019.

Langkah-langkah untuk menganalisis data dijabarkan sebagai berikut: 1) Menyiapkan data bencana alam Kabupaten Karanganyar dan data peta Indonesia.shp dengan unit terkecil kecamatan (dapat diunduh di bit.ly/pengabdian-stat-uns). 2) Membuat peta Kabupaten Karanganyar dengan langkah berikut: a) Membuka file peta Indonesia.shp di software Geoda, b) Klik gambar tabel pada menu toolbar Geoda, c) Mengurutkan kolom kode kabupaten dengan cara double klik pada header kode kabupaten, d) Pilih setiap baris dengan kode kabupaten 3313 (Kabupaten Karanganyar), dengan cara klik sambil menekan tombol CTRL, e) Klik kanan pada area bebas, pilih save selection, lalu klik Apply. Setelah itu, akan muncul kolom variabel tambahan dengan SELECTED, f) Klik file, pilih Save Selected As, pilih tipe file (*.shp), pilih lokasi penyimpanan, kemudian save, g) Centang Create a project File, lalu OK dan save. Setelah itu, peta Kabupaten Karanganyar akan tersimpan pada lokasi yang telah dipilih. 3) Membuka file peta Kabupaten Karanganyar.shp menggunakan software Geoda. 4) Menginputkan data kejadian bencana tanah longsor dengan langkah berikut: a) Klik gambar tabel pada menu toolbar Geoda, b) Klik kanan pada tabel, lalu pilih add variable, c) Memberi nama variabel misal "Tanahlongsor", kemudian klik Add, d) Membuka file data bencana alam Karanganyar, e) Menginputkan jumlah kejadian tanah longsor pada kolom "Tanahlongsor". 5) Membuat peta rawan bencana tanah longsor Kabupaten Karanganyar dengan langkah berikut: a) Klik Map, pilih Natural Breaks Map, lalu pilih jumlah klasifikasi (misal 3), b) Pilih variable "Tanahlongsor", lalu klik OK. Selanjutnya akan muncul warna-warna pada setiap kecamatan di peta Karanganyar berdasarkan jumlah kejadian tanah longsor. 6) Menyimpan peta rawan bencana tanah longsor Kabupaten Karanganyar dengan langkah berikut: a) Klik Options pada menu toolbar Geoda, lalu pilih Save Image As, b) Atur letak legend dan resolusi, kemudian klik Save, c) Memberi nama file, memilih tipe file, dan klik Save.

\section{HASIL DAN PEMBAHASAN}

Kabupaten Karanganyar merupakan salah satu Kabupaten di Provinsi Jawa Tengah yang rawan terjadi bencana alam. Bencana alam yang sering terjadi Kabupaten Karanganyar adalah tanah longsor, kebakaran, dan angin ribut. Berikut adalah rekap data jumlah bencana tanah longsor di Kabupaten Karanganyar pada tahun 2016-2019 berdasarkan kecamatan.

Tabel 1. Data Rekap Jumlah Kejadian Tanah Longsor di Kabupaten Karanganyar 2016-2019

\begin{tabular}{clc}
\hline No & \multicolumn{1}{c}{ Kecamatan } & Tanah Longsor \\
\hline 1 & Jatipuro & 14 \\
2 & Jatiyoso & 131 \\
3 & Jumapolo & 18 \\
4 & Jumantono & 12 \\
5 & Matesih & 38 \\
6 & Tawang Mangu & 83 \\
7 & Ngargoyoso & 164 \\
8 & Karang Pandan & 64 \\
9 & Karang Anyar & 2 \\
10 & Tasikmadu & 1 \\
11 & Jaten & 0 \\
12 & Gondangrejo & 5 \\
13 & Kebak Kramat & 1 \\
14 & Mojogedang & 0 \\
15 & Kerjo & 18 \\
16 & Jenawi & 52 \\
\hline
\end{tabular}

Berdasarkan Tabel 1 dapat diketahui jumlah kejadian tanah longsor pada setiap kecamatan di Kabupaten Karanganyar. Data tersebut dapat dibuat visualisasi dalam bentuk peta tanah longsor Kabupaten Karanganyar menggunakan software Geoda. Visualisasi data tanah longsor dalam bentuk 
peta mampu memberikan gambaran atau deskripsi yang lebih menarik dan informatif bagi para pembaca. Hasil visualisasi data tanah longsor Kabupaten Karanganyar menggunakan Geoda disajikan dalam Gambar 3.

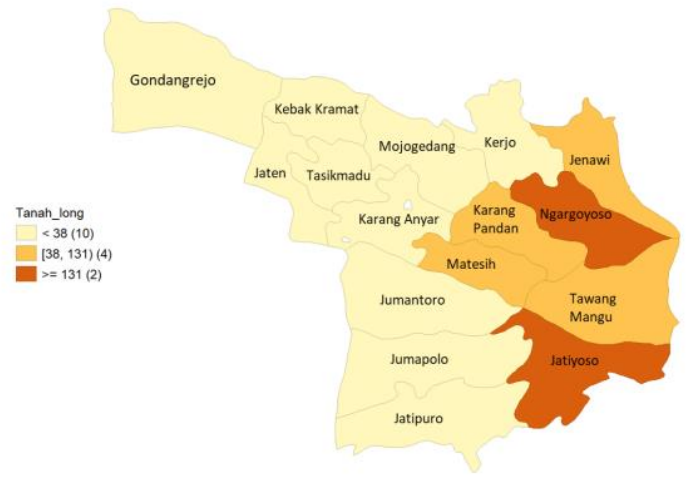

Gambar 3. Peta Kejadian Tanah Longsor di

Kabupaten Karanganyar Tahun 2016-2019

Gambar 3 menunjukkan peta kejadian tanah longsor di Kabupaten Karanganyar tahun 20162019. Semakin gelap warna suatu kecamatan menunjukkan bahwa semakin tinggi jumlah kejadian tanah longsor di kecamatan tersebut. Berdasarkan Gambar 3 dapat diketahui bahwa, selama tahun 2016-2019 Kecamatan Ngargoyoso dan Jatiyoso memiliki frekuensi kejadian tanah longsor paling tinggi yaitu lebih dari sama dengan 131 kali kejadian. Kecamatan Matesih, Tawang Mangu, Karang Pandan, dan Jenawi memilik frekuensi kejadian longsor sedang yaitu antara 38 sampai 130 kejadian. Sedangkan Kecamatan lain yang berwarna paling terang, memiliki kejadian longsor kurang dari 38 kali dalam 4 tahun terakhir (2016-2019).

Gambar 4 menunjukkan peta kejadian kebakaran di Kabupaten Karanganyar tahun 20162019. Semakin gelap warna suatu kecamatan menunjukkan bahwa semakin tinggi jumlah kejadian kebakaran di kecamatan tersebut. Berdasarkan Gambar 4 dapat diketahui bahwa, selama tahun 2016-2019 Kecamatan Karang Pandan memiliki frekuensi kejadian kebakaran paling tinggi yaitu lebih dari sama dengan 106 kali kejadian. Kecamatan Karanganyar, Matesih, dan Ngargoyoso memiliki frekuensi kejadian kebakaran sedang yaitu antara 25 sampai 106 kejadian. Kecamatan lain yang berwarna paling terang (ada 12 kecamatan) memiliki jumlah kejadian kebakaran kurang dari 25 kali dalam 4 tahun terakhir (2016-2019). Selanjutnya, Gambar 5 menyajikan visualisasi data kejadian bencana angin ribut di Kabupaten Karanganyar.

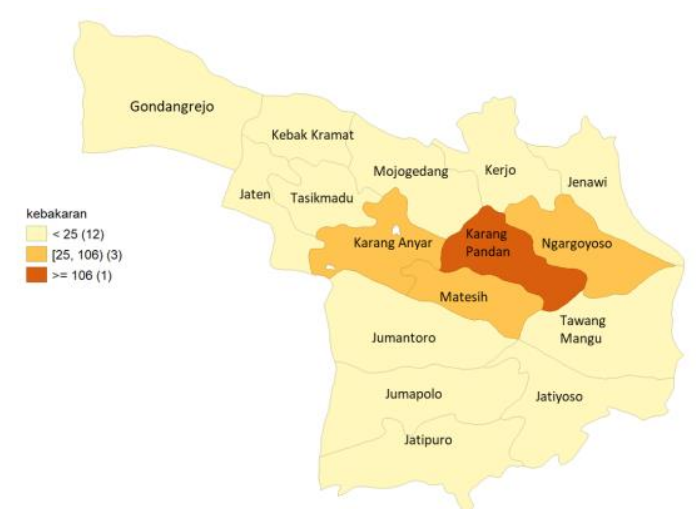

Gambar 4. Peta Kejadian Kebakaran di Kabupaten Karanganyar Tahun 2016-2019

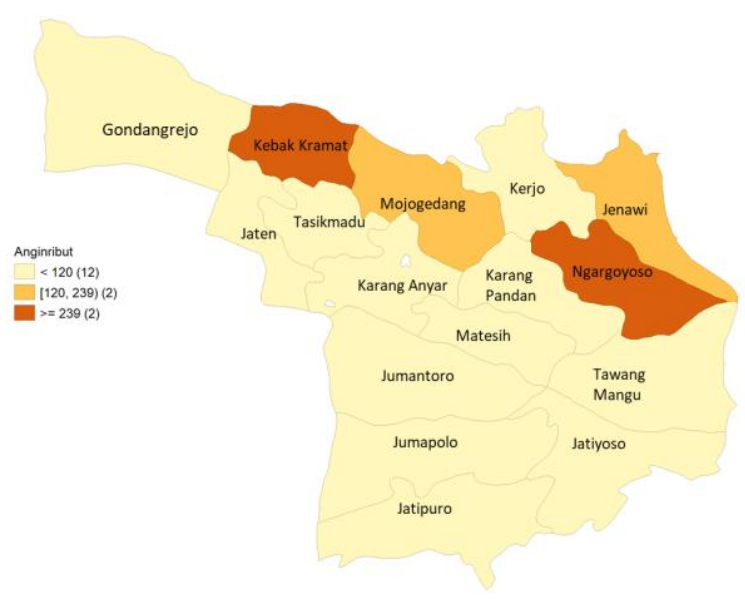

Gambar 5. Peta Kejadian Angin Ribut di Kabupaten Karanganyar Tahun 2016-2019

Gambar 5 menunjukkan peta kejadian angin ribut di Kabupaten Karanganyar tahun 2016-2019. Semakin gelap warna suatu kecamatan menunjukkan bahwa semakin tinggi jumlah kejadian angin ribut di kecamatan tersebut. Berdasarkan Gambar 5 dapat diketahui bahwa, selama tahun 2016-2019 Kecamatan Kebak Kramat dan Ngargoyoso memiliki frekuensi kejadian angin

Lingkungan Hidup dan Kebencanaan 
ribut paling tinggi yaitu lebih dari sama dengan 239 kali kejadian. Kecamatan Mojogedang dan Jenawi memiliki frekuensi kejadian angin ribut sedang yaitu antara 120 sampai 239 kejadian. Kecamatan lain yang berwarna paling terang, sejumlah 12 kecamatan, memiliki jumlah kejadian angin ribut kurang dari 120 kali dalam 4 tahun terakhir (20162019).

\section{KESIMPULAN}

Dengan menggunakan Geoda, dapat dilakukan pemetaan bencana alam di Kabupaten Karanganyar menurut kecamatan. Kecamatan Ngargoyoso dan Kecamatan Jatiyoso memiliki frekuensi kejadian tanah longsor tertinggi, sedangkan Kecamatan Karangpandan memiliki frekuensi kejadian kebakaran tertinggi. Untuk kejadian angin ribut, Kecamatan Kebak Kramat dan Ngargoyoso memiliki frekuensi tertinggi. Berdasarkan peta terlihat juga bahwa tanah longsor sering terjadi di wilayah Kabupaten Karanganyar bagian timur, kebakaran sering terjadi di bagian tengah, dan angin ribut di bagian utara.

\section{UCAPAN TERIMAKASIH}

Ucapan terima kasih disampaikan kepada Universitas Sebelas Maret atas dukungannya melalui Hibah Pengabdian Grup Riset dana PNBP UNS tahun 2020.

\section{REFERENSI}

BPBD Karanganyar. 2019. Pembentukan

BPBD. Retrieved from BPBD Kabupaten
Karanganyar:

http://bpbd.karanganyarkab.go.id/?p=1.

BPS Kab. Karanganyar. 2019. Karanganyar

Dalam Angka 2019. Karanganyar: BPS Karanganyar.

Furqon, M. T. and Muflikhah, L. 2016. Clustering the Potential Risk of Tsunami Using Density Based Spatial Clustering of Application With Noise. Journal of Environmental Engineering \& Sustainable Technology. Volume 3, pp. 1-8.

Kabupaten Karanganyar. 2011. Peta Karanganyar. Retrieved from Kabupaten Karanganyar:

http://www.karanganyarkab.go.id/20110104/admini strasi-wilayah/ peta-karanganyar/

Zhou, L., Xianhua Wu, Zeshui Xu, Hamido Fujita. 2018. Emergency decision making for natural disasters: An overview. International Journal of Disaster Risk Reduction. 2212-4209. Volume 27, pp. 567-576.

Pratiwi, H., Subanar, and Danardono. 2014. Analysis of Earthquake Data Based on Space-Time Epidemic Type Aftershock Sequence Model, International Journal of Applied Mathematics and Statistics. Volume 52, No. 2, pp. 55-62.

Ahmed, Z. 2013. Disaster risks and disaster management policies and practices in Pakistan: A critical analysis of Disaster Management Act 2010 of Pakistan. International Journal of Disaster Risk Reduction. 2212-4209. Volume 4, pp. 15-20.. 